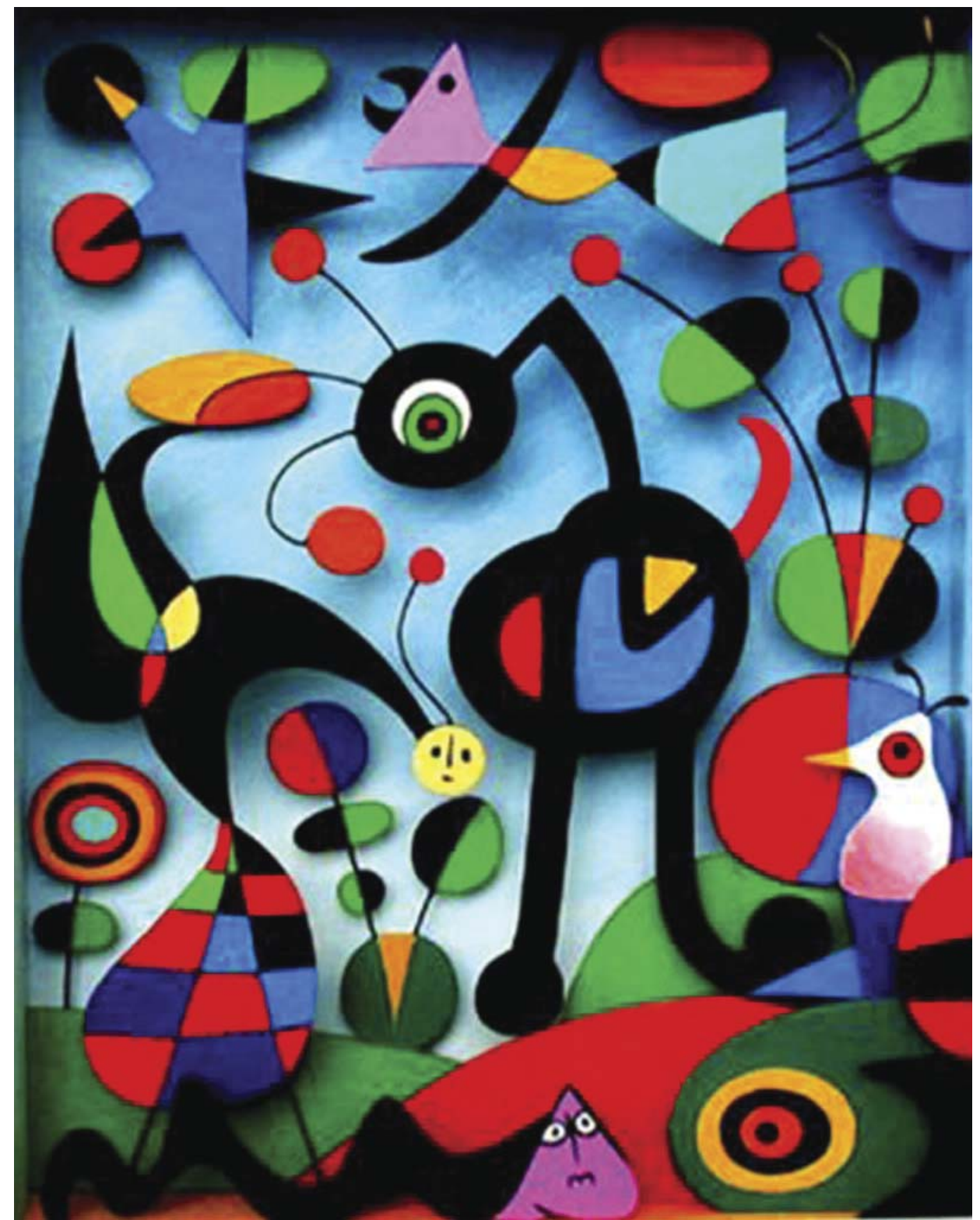

The Garden by J. Miro 


\title{
The Semiotic Interpretation of Joan Miro's World of Signs
}

\author{
Armine Matevosyan, Nazeny Hovakimian \\ Yerevan State University \\ "I try to apply colors like words that shape poems, \\ like notes that shape music." \\ Joan Miro
}

\begin{abstract}
The following article is devoted to the semiotic interpretation of some paintings by an outstanding Catalonian artist, Joan Miro. Here an attempt is made to concentrate on the symbolic objects, the colours and the whole mood of Miro's paintings, as well as to the emotional state of the artist himself, his descriptions of his art to bring out the link between linguistic and artistic signs.
\end{abstract}

Key words: semiotics, sign, art, visual language, interpretation.

\section{Introduction}

The subject-matter of the following article is Art Semiotics and, particularly, the link between artistic and linguistic signs. We shall draw your attention to some paintings by an outstanding Catalonian artist Joan Miro and try to understand the nature of his art by means of not only artistic signs, i.e. the symbols used in paintings, but also which is mostly important for our research, through linguistic signs, words used in his own descriptions of his art and his pictures.

\section{The Study of Signs}

The study of semiotics, or semiology originated and evolved in France, particularly in the works of Ferdinand de Saussure and has been expanding in a number of directions since the early turn-of-the century work of Charles Sanders Peirce and Claude Lévi-Strauss.

A sign can be a word, a sound, or a visual image. Saussure differentiated between signified and signifier. The part of the sign Saussure calls the concept or meaning (mental impression/association of the thing) is the signified in his terms. The part he calls the soundimage (the mental linguistic sign given to the thing) is the signifier. As Saussure explains, the connection between all signifiers which are sound images or linguistic signs and what they are signifying - their signified object or concept - is arbitrary. In other words, there is not necessarily any logical connection between the two (Saussure 2006).

Semiotics focuses mainly on units of meaning and the generalizable conditions for encoding across symbolic systems (linguistic, visual, auditory), and, in general, uses language as the modeling system for other second order systems that function according to systematic rules (e.g., visual art, music, literature, popular media, advertising, or any meaning system) (Irvine 2004).

\section{Visual Versus Verbal}

All painters work in a pictorial language by following a set of standards of picturemaking. Actually there is a big resemblance between pictorial image making and the cre- 
ation of written language. Through semiotics one can translate a picture from an image into words. Visual communication terms and theories come both from linguistics and semiotics. Signs may take the form of images, sounds, acts or objects, even odours but they become signs only when one provides them with meaning.

Everything that surrounds us is manipulated by signs, words, images and visual language. Communication can be seen as a form of mind control; it has a great power. The same can be true for artworks which may activate people's minds. Visual language covers a whole range of different social mediums from advertising, commixes and television to high culture, including galleries and theatres.

Language becomes complicated if we look at it from a new angle - that is from the angle of visual artworks. Here we have to deal with symbolic and conventional meanings. Just as people can verbalize their thinking, they can visualize it as well. Speech and visual communication are parallel and often interdependent means by which people exchange information.

Pictorial Semiotics is often concerned with the study of pictures into a more constructive verbal description while maintaining confidence in the objectivity of the practice (Chandler 2004). It is said that the painter works like a poet; first the word, then the thought - this quote describes how artists and poets may see or think of a concrete image or a word before they have formulated the idea or symbolism behind it.

Art is the expression of artist's inner state, his thoughts, feelings, emotions, hopes, desires, wishes, dreams on the one hand, and his disappointments, fears, despairs, misfortunes, on the other. And all this can be seen in the artist's works through different scenes and signs. What is interesting, that most artists don't like speaking about their works, maybe because they think that whatever can be seen and felt is more than can be said by means of the spoken language. But whenever an artist speaks about his works or even about himself, it becomes clear how his words are interrelated with his art, and how what is spoken can be replaced by what is created by means of various colors and shapes. To prove whatever has been said above, we would like to illustrate some of Juan Miro's paintings and try to connect his world of artistic signs with that of linguistic ones.

\section{Joan Miro's World of Signs}

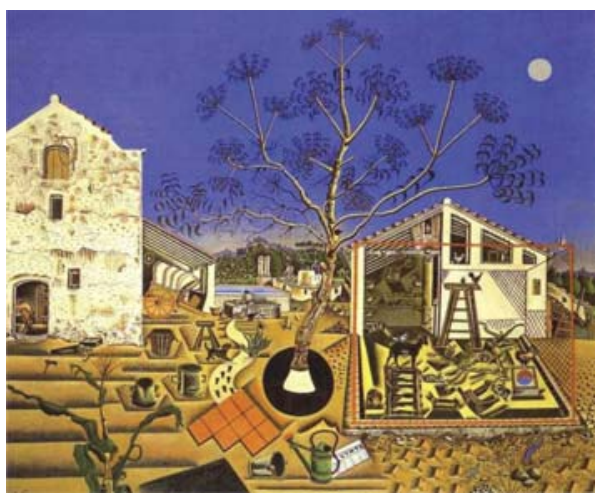

The Farm, 1921-1922
Miro pursued his own interests in the art world, ranging from automatic drawing and surrealism to expressionism, lyrical abstraction and color-field painting. In some of his works color becomes an object in itself and everything is seen through colors.

In 1920-s Miro draws "The Farm". Anything that you see in the pictures is close to Miro's heart, it's his Catalan countryside. Miro mentions that for him a tree is not just a tree, something that belongs to nature, but it's something human, a living thing. Tree is a personage. It's a talking personage. It can 
see and hear... (George Rayar, Yuri Khachatryan 2004). All the elements of this painting, animals and objects are in the form of symbols that would appear later in Miro's works - a dog, a goat, a rabbit, snails, insects, the ladder, etc.

Miro once said: "For me art is never something abstract; it is always a sign of something. It is always a man, a bird, or something else. For me painting is never for form's sake..." (Chipp 1968:432).

Miro mentions that ladder is a recurrent form in his works. In the fisrt years it was a plastic form frequently appearing because it was too close to him - a familiar shape in The Farm. In later years, particularly during the war it came to symbolize escape. So, being an essentially plastic form at first, it became poetic later (ibid 432).

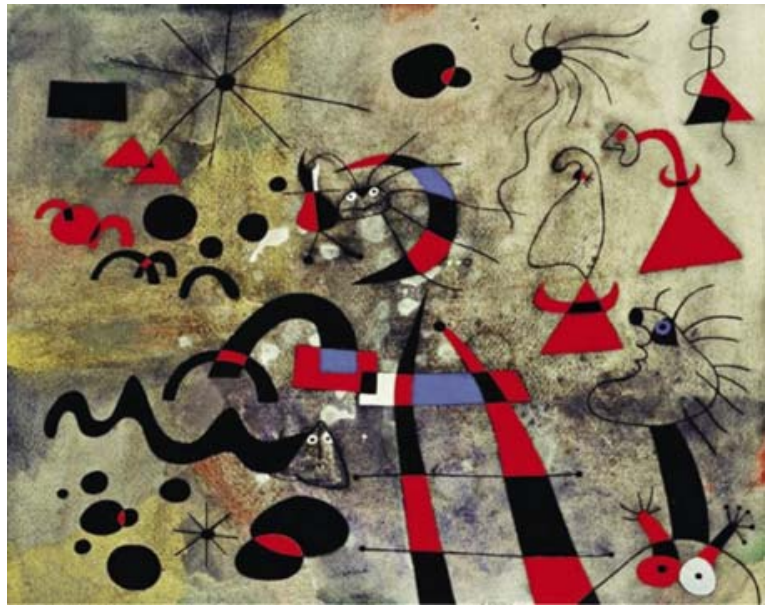

L'echelle de l'evasion/ The escape ladder, 1940 (from Constellation series)

Here the ladder becomes the symbol of escape. Surely, its message is that art can offer refuge from the reality.

It's not just by coincidence that Miro's work is rich in signs and can be seen as related to language. It's important to note that during his life he was in close relations with poets, especially with surrealists (Breton, Artaud, Elouard) and he enjoyed reading, that's why his art somehow resembles poetry. Once he mentioned: "Poetry endows me with new opportunities to rise above the rules of painting" (George Rayar, Yuri Khachatryan 2004:10). Miro tries to fight with the materialization of the world to reach a real poetry. His work illustrates the subconscious world as existing with the conscious one. According to the artist, he was taken in by hunger-induced hallucinations involving his impressions of poetry. These resulted in his "dream paintings," such as Personage (Personnage), in which ghostly figures linger in a bluish ether. Although these images are highly schematic, they are not without references to real things, as the artist made clear. "For me a form is never something abstract," he said in 1948. "It is always a sign of something. It is always a man, a bird, or something else" (Joan Miró, interview by James Johnson Sweeney, in "Joan Miró: Comment and Interview," Partisan Review 15, no. 2, February 1948, pp. 208-212).

In these works Miró began to develop his own language of enigmatic signs: the forms in Personage depict a large vestigial foot and a head with three "teeth" in its grinning mouth. The star shape often represents female genitalia in Miró's work and the dot with four rays symbolizes the vision of a disembodied eye. 


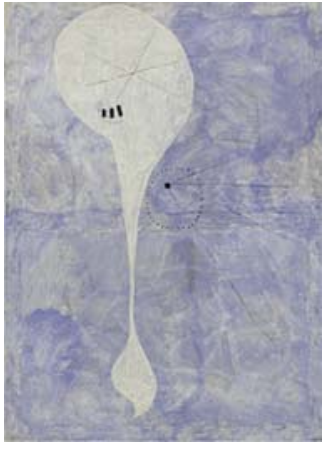

Personage

(Personnage), 1925.

Spain's destiny.

Translated, the inscription reads, "In the current conflict on the Facist side I see massive forces, and on the other side are the people whose immense and creative resourcefulness will give Spain a vitality which will astonish the world.'

Miro's political conscience was awakened by the Spanish Civil War. Catalonia was a key battleground. He responded to this with an incandescent, monstrously distorted still-life table emerging out of the dark. Here apple is the symbol of Spain. Its objects could not be more ordinary and simple - a fork, a bottle, an apple, a loaf of bread - yet these homely realities seem threatened by a kind of hallucino-

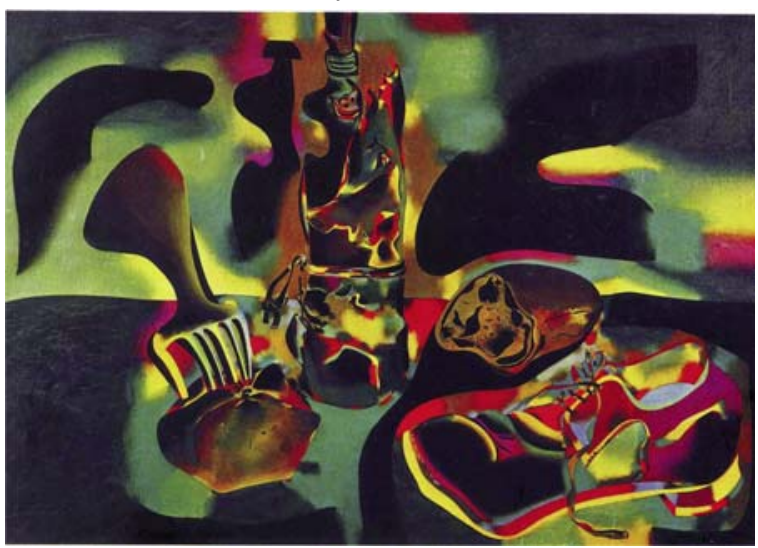

Still Life with Old Shoe, 1937

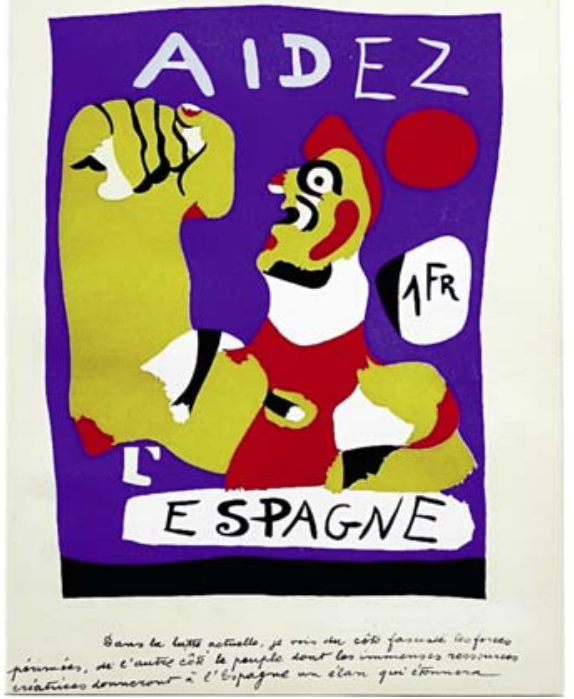

Aidez l'Espagne , 1937

genic doom. "The civil war was all bombings, death, firing squads..." Miró wrote to his dealer Pierre Matisse, "The composition is realistic because I was paralysed by the general feeling of terror and almost unable to paint at all... We are living through a terrible drama, everything happening in Spain is terrifying in a way you could never imagine. I feel very uprooted here and nostalgic for my country..." (Adams 2011). 
Struck by the image of the fork stabbing a dried apple and the ominously flowing areas of blackness, critics have read the painting as an allegory about the Spanish Civil War. What is immediately captivating about it, though, is how the rustic objects seem to glow mysteriously from within. It is an image of supernatural immanence in the humblest of circumstances.

There is a conspicuous difference between Still Life with Old Shoe and a work like Aidez l'Espagne, the poster of a brawny Catalan peasant with his fist upraised in Republican salute and threatening to smash the Fascist enemy. Designed to be reproduced widely, Aidez has a clear propagandist purpose and represents a public show while in Still Life we see Miro's personal feelings towards the revolution, his disability to fight against injustice.

It's as if Miró knew deep down that the uneasy Republican coalition of liberals, socialists, etc. stood little chance against the military might of Franco (a Spanish military leader who ruled as the dictator of Spain from 1939 to his death in 1975). But on the surface, he projected confidence, producing works like Aidez l'Espagne in solidarity with the Republican cause.

In the years of World War Miro moves to the country. Here he creates his famous "Constellation Series". It seems that in this quiet countryside he takes a new breath. Miro creates a new reality where poetry and music rule. It seems that going deeper to the world of symbolic language he wants to hide away from the tough reality, find a spiritual release and quietude in his gentle tones, slight lines, musical surfaces.

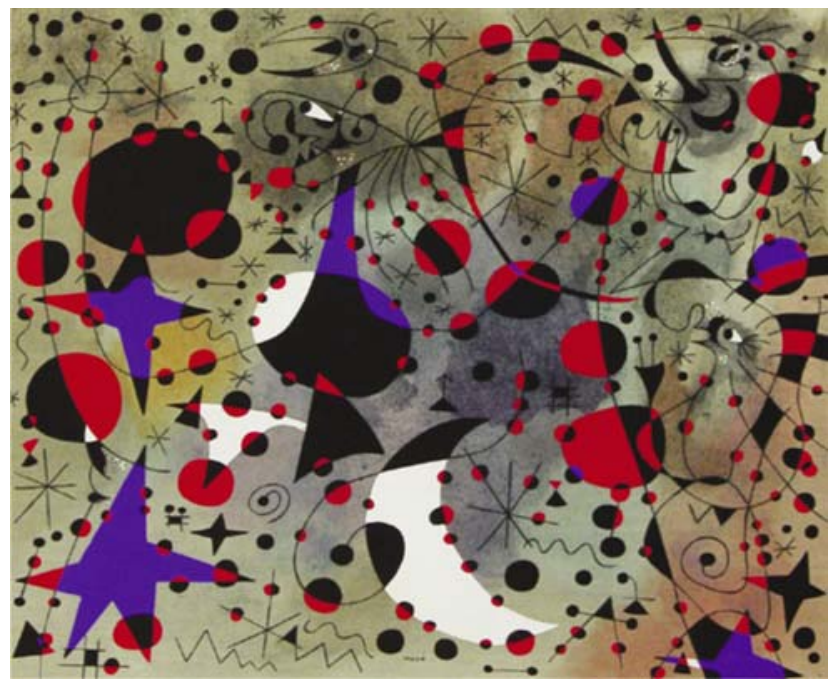

Personnages dans la nuit guides par les traces phosphorescentes des escargots (People at night guided by the phosphorescent trails of snails), 1940

Miro once mentioned that the titles of his works appear gradually, while working, and mostly in French. The above introduced painting from "Constellation" series with a poetic French title is characterized by shapes of stars, birds and women. The title of the picture should be taken into consideration as both in French and in English variants it bears some musicality in it. In both variants there are alliterations and the sounds $/ \mathrm{p} /$, $/ \mathrm{n} /, / \mathrm{s} /$, /f/, /t/ make an interesting and calm atmosphere as if we "hear the sounds of the night'. It seems that Miro created his own language. Here we see black dots which represent stars. The colors and all the shapes seem to create a moving, dancing atmosphere. 
The dots representing stars can even be called painted poetry due to their visually poetic nature. As it has already been mentioned this was the period of World War II and during this period Miro saught to find a new reality. His works of this period are influenced by night, music and stars. His forms become more and more abstracted. These stars seem to be a way to the universe, they are a door to escape from the war, from the brutality of the world. As Miro's grandson put it; "It is as if Miró was a nocturnal bird able to escape from the earth, leaving the sky, traveling across the sky, the stars, to the constellations, to capture them all with one hand, and draw back to earth them on a sheet of paper" ("Fragments of interview of Joan Punyet". El meu avi (in Catalan). TV3. Retrieved 2011-10-30).

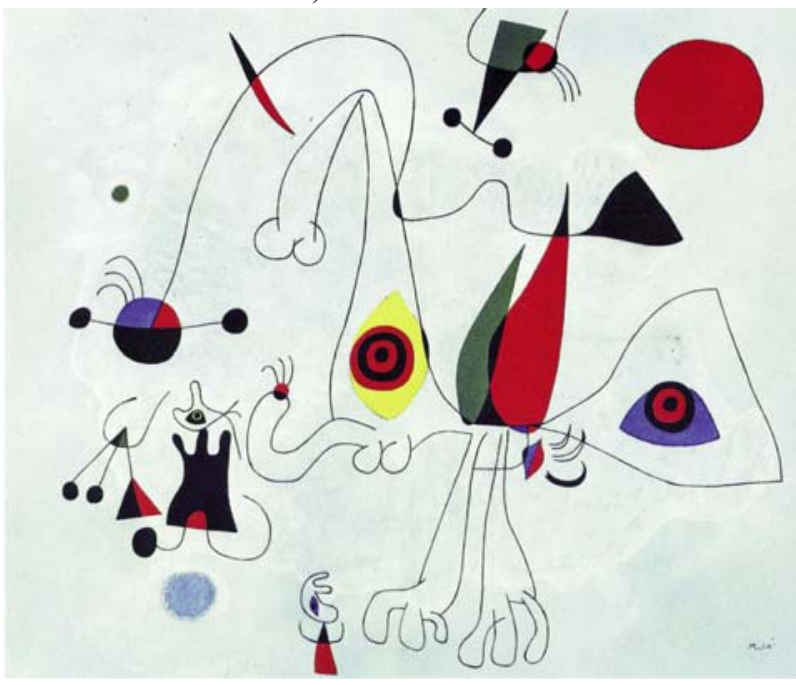

Women and birds in sunrise, 1946

As you may have already noticed, women and birds are recurrent themes in Miro's works. Miro once mentioned that for him a woman doesn't mean just a woman as a being, but a whole universe. Miro's surrealism is seen here as supposed to be a fusion of reality and dream, a sort of super-reality.

\section{Conclusion}

So, when interpreting a sign a number of factors should be taken into consideration, beginning from the artisit's age to his experiences and emotional states. We may conclude that thoughts that are born in a painter's mind are transformed to images, colors and shapes and are interpreted by viewers as signs denoting this or that reality, this or that idea. Besides, titles of pictures can also be taken into consideration only in case they are created by the painter himself, as this will allow the researcher to see some interesting points and to draw parallels between the painter's world expressed in colors and his world expressed in words.

There is just too much life in Miro's art; it can be seen in his different shapes and colors; too much life means that there is too much to be grasped and understood from his art. Here, even emptiness pulses with energy. Miro's art bears much to his motherland Catalonia, his art and his soul were rooted in there, in his sunny motherland. Deep down, Miro's art has a fantastic, irrepressible quality. It is about liberating the imagination. This is what semiotic study allows us to do. Thus, one should have a free and limitless imagination to understand the world of artistic signs and symbols. 


\section{References:}

1. Chandler, D. (2004) Semiotics: the Basics Taylor \& Francis e-Library. Available at: $<\mathrm{http}$ //dominicpetrillo.com/ed/Semiotics_for_Beginners.pdf $>$ [Accessed April 2013]

2. Chipp, H. (1968) Theories of Modern Art. California: University of California Press.

3. Rayar, G.; Khachatryan, Y. (2004) Joan Miro, sa im yerazneri guynn e. / Zruycner George Rayari het. / Tr. by A. Boyajyan, Yerevan: Sargis Khachents Press.

4. Saussure, F. (2006) Writings in General Linguistics. Oxford: OUP

\section{Sources of Data:}

1. Adams, T. Joan Miro: A Life in Paintings. Available at: $<$ http://www.theguardian.com/ artanddesign/2011/mar/20/joan-miro-life-ladder-escape-tate $>$ [Accessed March 2011]

2. Hospers, J. Symbols in Art. Available at: <http://www.britannica.com/EBchecked/ topic/36433/art-philosophy-of/36270/Symbols-in-art> [Accessed April 2013]

3. Irvine, M. Structural Linguistics, Semiotics and Communication Theory: Basic Outlines and Assumptions. Available at: <http://www9.georgetown.edu/faculty/irvinem/ theory/Semiotics_and_Communication.html> [Accessed May 2013]

4. National Gallery of Art, Joan Miro, The Ladder of Escape. Available at: $<$ http://www.nga.gov/exhibitions/2012/miro/index.shtm> [Accessed March 2013]

5. Online Collection, Joan Miro. Available at: $<$ http://www.guggenheim.org/new-york/collections/ collection-online/artwork/2935> [Accessed April 2013]

6. Visual Art Encyclopedia, Joan Miro. Available at: $<$ http://www.wikipaintings.org/ en/search/joan\%20miro/1> [Accessed May 2010]

\section{IUnufi Uhpnjh uplthump G2ufiuqhunuluufi uthlinıpjnıfin}

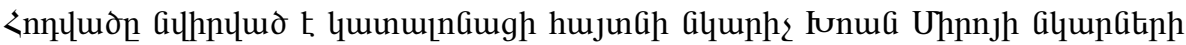

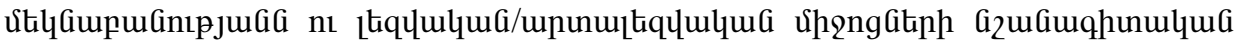

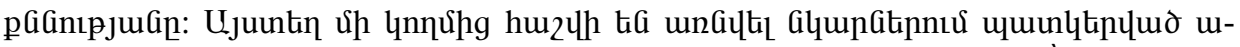

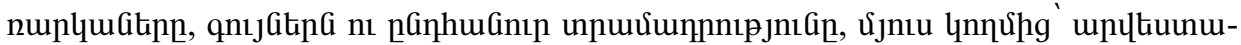

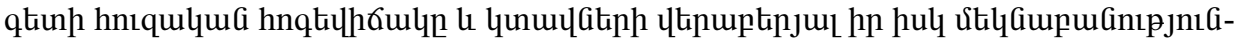
Gitin:

\section{Семиотическая интерпретация знаков в искусстве Жоана Миро}

Статья посвящена художественной семиотике. Это попытка найти связь между живописными и лингвистическими знаками. В статье представлены некоторые рабо- 
ты известного каталонского художника Жоана Миро, которые рассматриваются с точки зрения сочетания лингвистических и живописных знаков. Учитываются как изображенные обьекты, гамма красок и общий настрой произведений, так и эмоциональное состояние автора, выраженное в его высказываниях о своем исквусстве. 